\title{
Serum Apelin Level in Normal and Gestational Diabetic Rats: Effect of Treatment with Vitamin D
}

\author{
MAHA A. FATHY, M.D. and REHAM H. IBRAHIM, M.D. \\ The Department of Medical Physiology, Faculty of Medicine, Zagazig University, Egypt
}

\begin{abstract}
Background: Apelin peptide was identified in a wide variety of tissues including adipose tissue and it was linked to glucose homeostasis in obesity and diabetes. Apelin and its receptors were also identified in the placenta, and play a role in fluid and glucose transport. Vitamin D affects glucose metabolism and its deficiency was linked to gestational diabetes.
\end{abstract}

Aim of the Study: To estimate serum apelin level in normal and gestational diabetic rats and to study the effect of Vitamin $\mathrm{D}$ administration on serum apelin level in relation to some metabolic parameters in gestational diabetes.

Material and Methods: Healthy adult female albino rats were divided into the following groups, Group I $(n=8)$ : Virgin control rats; Group II $(\mathrm{n}=16)$ : Normal pregnant control group (NP) subdivided into Group IIa $(\mathrm{n}=8)$ sacrificed on day 11 and Group IIb ( $\mathrm{n}=8)$ sacrificed on day 19 of gestation; Group III $(n=22)$ : Gestational Diabetic group (GDM), rats were subdivided into Group IIIa $(\mathrm{n}=11)$ sacrificed on day 11 and Group IIIb (n=11) sacrificed on day 19; Group IV (n=11): Gestational diabetic Vitamin D3 treated group (GDM + vit D3), gestational diabetic rats received vitamin D3 $(50 \mathrm{IU} / \mathrm{kg}$ / day) intra-peritoneal from day 10 till sacrificed on day 19 The following parameters were measured in all groups: BMI, blood glucose, serum insulin, lipid profile, $\mathrm{C}$ Reactive Protein (CRP), Tumor Necrosis Factor a (TNFa) and HOMA-IR was calculated.

Results: A significant increase in serum apelin level was found on day 11, while a significant decrease was found on day 19 of normal gestation relative to non-pregnant level. In GDM groups, apelin level significantly decreased in Group IIIa compared to Group IIa and in Group IIIb compared to Group II b. Vitamin D3 induced a significant increase in apelin level in Group IV compared to Group IIIb. Serum apelin level correlated negatively with blood glucose, HOMA-IR, TC, LDL and TNFa in Group III and IV.

Conclusion: Gestational diabetes induced significant decrease in serum apelin level in pregnant rats compared to normal pregnant gestational age matched control. Vitamin D3 supplementation in gestational diabetic rats induced significant increase in apelin level in association with a decrease in insulin resistance.

Correspondence to: Dr. Maha A. Fathy, E-Mail: y maha m@hotmail.com
Key Words: Gestational diabetes - Insulin - HOMA-IR Apelin-Vitamin D.

\section{Introduction}

APELIN is a biologically active peptide that exerts its action through binding to its specific G-protein coupled receptor APJ. Apelin and its receptors are expressed in a wide variety of tissue including brain, heart, blood vessels, lung and adipose tissue [1]. It was involved in regulation of cardiovascular function, blood pressure and fluid homeostasis [2] A metabolic role for apelin was also identified as it was reported to increase glucose uptake [3], improve insulin sensitivity $[4]$ and modulate $\beta$ cell function [5] which led to a great concern to study the possible link between apelin and different metabolic disorders especially obesity and diabetes but the results were variable. Some investigators found an increase in apelin level in type 2 diabetic subjects [6], while others reported a decrease in apelin level in newly diagnosed and untreated type 2 diabetic patients [7].

Pregnancy is associated with several metabolic changes to secure fetal nutritional needs throughout pregnancy including hyperinsulinemia, insulin resistance and altered lipid profile [8]. Apelin and its receptors were found to be expressed in placental tissue. It was suggested to play a role in angiogenesis during placental growth, glucose and fluid transport across the placenta [9]. These data indicates a possible role for apelin in pregnancy associated disorders as preeclampsia, fetal growth retardation and gestational diabetes [10]. Gestational diabetes mellitus is glucose intolerance that is manifested first during pregnancy and usually diagnosed in the second or third trimester. Its incidence shows progressive increase with adverse maternal and fetal outcomes during and after delivery [11]. However, only few studies about apelin 
level in gestational diabetes are available with conflicting results. While one study reported an elevation in apelin level in GDM [12], another study reported no significant change [13] and even a third one revealed a decrease in apelin level [14].

Vitamin D markedly increases during pregnancy up to 2 folds from 1 st to 3 rd trimester relative to non-pregnant levels. It plays several skeletal and extra-skeletal roles involving numerous effects on glucose metabolism [11]. Several studies demonstrated an association between gestational diabetes and Vitamin D deficiency $[\mathbf{1 1}, \mathbf{1 5}, \mathbf{1 6}]$. Some investigators reported a favorable effect of Vitamin D on insulin resistance and glucose tolerance in gestational diabetes [17]. Others reported absence of an association between Vitamin D deficiency and gestation diabetes [18,19] with no effect of Vitamin $\mathrm{D}$ treatment on insulin resistance in these patients [20].

From the previously mentioned inconsistent findings, the present study was designed to study changes in serum apelin level in normal and gestational diabetic rats and declare the possible effects of Vitamin D3 administration on serum apelin level in these rats and find out whether these effects are linked to some metabolic and inflammatory parameters.

\section{Material and Methods}

Animals: From July 2017 to March 2018, the present study was conducted on 68 adult female albino rats (8-9 weeks, $150-170 \mathrm{~g})$ and 6 adult male albino rats for fertilization (8-10 weeks, 150-200g) were obtained from Animal House Faculty of Veterinary Medicine, Zagazig University. The animals were bred in animal house Zagazig University and kept in steel wire cages measured $90 \mathrm{~cm} \mathrm{X} 40 \mathrm{~cm}$ $X 30 \mathrm{~cm}$ (6-8/cage). The rats had free access to water and chow, kept at room temperature on a natural light/dark cycle. The rats were accommodated to laboratory conditions for 1 week then rats were randomly divided into the following groups:

Group I $(n=8)$ : Virgin rats fed on Standard Diet (SD) $(60 \%$ starch, 5\% corn oil and $20 \%$ casein protein) [21] and sacrificed at the end of the experiment.

Group II $(n=16)$ : Normal pregnant group, rats in this group were fed on Standard Diet (SD) for 8 weeks before induction of pregnancy and onward. Oral Glucose Tolerance Test (OGTT) was done to pregnant rats on day 10 of gestation as control [22] It is further divided into 2 subgroups: Group IIa $(n=8)$, rats in this group were sacrificed on day 11 ;
Group IIb $(\mathrm{n}=8)$, rats in this group were sacrificed on day 19 of gestation.

Group III $(n=30)$ : Gestational Diabetic group (GDM), rats in this group were fed on High FatHigh Sucrose Diet (HFSD) (25\% sucrose, $40 \%$ beef tallow and $20 \%$ casein protein) [21] for 8 weeks [23], then OGTT was done and rats with impaired glucose tolerance were considered prediabetic and were enrolled into the study [22]. The pre-diabetic female rats $(n=25)$ were mated with healthy male rats for induction of pregnancy which failed in 3 rats. The pregnant rats $(n=22)$ continued on HFSD till the end of the experiment. The American Diabetes Association defined gestational diabetes mellitus as diabetes that is not clearly apparent diabetes, diagnosed in the second or third trimester of pregnancy [24], so OGTT was repeated on day 10 (mid gestation) to confirm GDM [22]. It is further divided into 2 subgroups: Group IIIa $(\mathrm{n}=11)$, rats in this group were sacrificed on day 11; Group IIIb $(n=11)$, rats in this group were sacrificed on day 19 of gestation.

Group IV $(n=14):$ GDM + vit D3 group, rats in this group were assigned to the same protocol used in Group III, on day 10 of gestation [24] after performing OGTT [22], rats diagnosed with gestational diabetes $(n=11)$ received daily intraperitoneal injection of Vitamin D3 (Puritan Co., Cairo, Egypt) at a dose of 50IU/kg/day [25] till sacrificed on day 19 of gestation.

OGTT was repeated on day 18 in Group IIb, $\mathrm{IIIb}$ and IV, one day before sacrificing the rats, a curve was drawn and the Area Under the Curve (AUC) was calculated to compare results.

Both SD and HFSD were obtained from Department of Nutrition, Faculty of Veterinary Medicine, Zagazig University. The procedures used in this experimental study are matched with the guiding principles for the care and use of research animals and were approved by the Institutional Research Board, Faculty of Medicine, Zagazig University.

Induction of pregnancy: Morning vaginal smears were examined using light microscope at 40x magnification to identify a 4 day estrous cycle: Proestrous (round nucleated epithelial cells); estrous (cornified or irregular shape of epithelial cells); metaestrous (few round cells); and diestrous (mostly small and round cells) [26]. When proved in the estrous phase, female was isolated and allowed to mate overnight with a mature male in a separate cage. In the next morning, vaginal smear was examined and copulation was confirmed by detec- 
tion of sperms which indicated day 1 of gestation [27].

Oral Glucose Tolerance Test (OGTT): The nonpregnant rats were fasted for 5 hs at least [28] and pregnant rats were fasted for $4 \mathrm{hs}$ only to avoid hypoglycaemia during pregnancy [22] then $2 \mathrm{~g} / \mathrm{kg}$ glucose was given orally by gavage and blood glucose was measured at 0, 30, 60 and 120min after glucose intake using one touch glucometer through tail vein puncture [29]. A curve was drawn by plotting glucose concentration (c) against time (t). Rats were defined to have Gestational diabetes when they have at least one elevated value of blood glucose with a threshold of: Fasting blood glucose $\geq 100 \mathrm{mg} / \mathrm{dl}$ and $2 \mathrm{hs} \geq 140 \mathrm{mg} / \mathrm{dl}[\mathbf{1 3}, 24]$

Then Area Under the Curve (AUC) was estimated as follow: $\mathrm{AUC}=(\mathrm{C} 1+\mathrm{C} 2) / 2 \mathrm{X}(t 2-t 1)$. $(\mathrm{C} 1+\mathrm{C} 2) / 2$ represent the average concentration in a given time interval, while $(t 2-t 1)$ is the duration of time interval. The equation was repeated for each time interval and the sum of all intervals represents the total AUC [28].

Body mass index: The weight and length (nose to anus length) were measured and BMI was calculated at the end of the experiment using the equation: BMI $\left(\mathrm{g} / \mathrm{cm}^{2}\right)=$ Body weight $(\mathrm{g}) /$ Length $^{2}$ $\left(\mathrm{cm}^{2}\right)[30]$.

Blood sampling: Animals were anesthetized using light ether then sacrificed by decapitation and blood samples (5-8ml/rat) were obtained. Blood was allowed to clot at room temperature then centrifuged at $3000 \mathrm{rpm}$ for $15 \mathrm{~min}$ and serum was stored at $-20^{\circ} \mathrm{C}$ till biochemical assay.

Biochemical assay: Serum apelin level was estimated by using rat apelin ELISA kit; (Catalog Number: 201-11-6020, Shanghai Sunred biological technology, China). Serum glucose level: Glucose enzymatic (GOD-PAP)-liquizyme Kits (Biotechnology, Egypt) was used as stated by Tietz, [31] Serum insulin level: Rat insulin enzyme-linked immunosorbent assay kit (Product Number: RAB0904, Sigma-Aldrich Chemie GmbH, U.S.A) was used according to Temple et al., [32]. Homeostasis model assessment of insulin resistance (HOMA-IR) by using the formula; [HOMA-IR= insulin (WU/nL) X glucose $(\mathrm{mg} / \mathrm{dL}) / 405] \quad[33,34]$ Serum Tumor Necrosis Factor- $\alpha$ (TNF- $\alpha)$ by rat ELISA kits according to Engelberts et al., [35] (Elabscience Biotechnology, USA. Cat: EELH0109). C Reactive Proteins (CRP) levels according to Ridker et al., [36] using CRP Kits (Monobind Inc. Lake Forest, Ca 92630, USA). Serum total cholesterol level by using rat cholesterol enzyme- linked immune-sorbent assay kit (Catalog Number: 2011-11-0198, Shanghai sunred biological technology, China) [31] . Serum triglycerides level: Rat triglycerides enzyme-linked immune-sorbent assay kit: (Catalog Number: 2011-11-0250, Shanghai sunred biological technology, China) was used according to Naito, [37]. Serum High Density Lipoprotein cholesterol level (HDL): Rat HDLcholesterol enzyme-linked immune-sorbent assay kit (Catalog Number: 2011-11-0255, Shanghai sunred biological technology, China) was used according to Nauk et al., [38]. Serum Low Density Lipoprotein cholesterol (LDL) level: LDL was recorded using the following folmula: $\mathrm{LDL}=\mathrm{TC}-$ HDL-TG/5 [39]

\section{Statistical analysis:}

Data were presented as mean \pm SD. Difference between the means was assayed by using analysis of variance (ANOVA) followed by post hoc test. $p$-values less than 0.05 were considered significant. The correlations between parameters were assayed by Pearson's correlation coefficient. All statistical analyses were performed using SPSS Version 18.0 program for Windows (SPSS Inc. Chicago, IL, USA).

\section{Results}

A significant increase in BMI was found in normal pregnant Groups (IIa and IIb) compared to non-pregnant group (Group I) $(p<0.01, p<0.001$ respectively). In GDM groups, significant increase in BMI was found in Group IIIa compared to Group IIa $(p<0.01)$ and in Group IIIb compared to Group IIb $(p<0.01)$. In Vitamin D3 treated Group (IV), no significant difference in BMI was found compared to GDM Group (IIIb) $(p>0.05)$ (Table 1).

Fasting blood glucose level significantly decreased in normal pregnant groups (Group IIa and IIb) versus non-pregnant group (Group I) $(p<0.001)$ and it was significantly lower in Group IIb than in Group IIa $(p<0.001)$. In GDM groups (Group IIIa and IIIb), blood glucose level significantly increased compared to normal pregnant groups (Group IIa and IIb respectively) $(p<0.001)$. In GDM + vit D3 group (Group IV), significant decrease in blood glucose level was found compared to GDM Group (IIIb) $(p<0.01)$ (Table 1).

Serum insulin level in normal pregnant Groups (IIa and IIb) revealed significant increase compared to non-pregnant group $(p<0.01$ and $p<0.001$ respectively). Serum insulin was significantly higher in Group IIb versus Group IIa $(p<0.01)$. In GDM Groups (IIIa and IIIb) serum insulin level showed 
significant increase compared to normal pregnant Groups (IIa and IIb respectively) $(p<0.001)$. In GDM + vit D3 Groups (IV), no significant difference in serum insulin levels was found versus Group IIIb $(p>0.05)$ (Table 1).

No significant increase in HOMA-IR was found in Group IIa compared to Group I $(p>0.05)$. In Group IIb, significant increase in HOMA-IR was found compared to Group I $(p<0.05)$ and Group IIa $(p<0.05)$. Significant increase was found in Group IIIa and IIIb versus Group IIa and Group IIb respectively $(p<0.001)$. In Group IV, Vitamin D3 induced significant decrease in HOMA-IR compared to Group IIIb $(p<0.01)$ (Table 1$)$.

In Group IIa, lipid profile parameters including TC, TG, LDL and HDL showed significant increase compared to Group I $(p<0.001, p<0.001, p<0.05$ and $p<0.001$ respectively), and also in Group IIb compared to Group I $(p<0.001)$ and Group IIa ( $p$ $<0.001, \mathrm{p}<0.001, \mathrm{p}<0.05$ and $\mathrm{p}<0.001$ respectively). In GDM groups TC, TG and LDL significantly increased in Group IIIa compared to Group IIa $(p<0.001)$, no significant difference was found in HDL levels in this group compared to Group IIa $(p>0.05)$. In Group IIIb, significant increase was found in TC, TG and LDL compared to Group IIb $(p<0.001)$, while HDL levels significantly decreased compared to Group IIb $(p<0.001)$. In Group IV, serum level of TC and LDL showed significant decrease ( $p<0.001, p<0.01$ respectively) but on significant change was found in TG and HDL level $(p>0.05)$ compared to Group IIIb (Table 1).

Serum apelin level showed significant increase in Group IIa versus Group I ( $p<0.05)$, while in Group IIb, its level significantly decreased versus Group I $(p<0.05)$. In GDM groups, serum apelin level significantly decreased in Group IIIa versus Group IIa $(p<0.05)$ and in Group IIIb versus Group IIb $(p<0.001)$. In GDM + vit D3 Group (IV), significant increase in apelin level was found versus Group IIIb $(p<0.05)$ (Table 1).

In Group IIa, no significant difference in CRP was found versus Group I $(p>0.05)$. TNF $\alpha$ levels showed significant increase in Group IIa versus Group I $(p<0.01)$. In Group IIb, serum level of CRP and TNF $\alpha$ significantly increased compared to Group I ( $p<0.05$ and $p<0.001$ respectively). In Group IIIa, CRP and TNF $\alpha$ were significantly higher compared to Group IIa ( $p<0.01$ and $p<0.001$ respectively) and in Group IIIb compared to Group IIb $(p<0.001$ and $p<0.001$ respectively). In GDM + vit D3 Group (IV), no significant difference in CRP $(p>0.05)$ but a significant decrease in TNF $\alpha$ was found compared to Group IIIb $(p<0.01)$ (Table $1)$.

Serum apelin level correlated negatively with blood glucose level in Group IIIa ( $r=-0.692$, $p<0.05)$, Group IIIb $(r=-0.703, p<0.05)$ and Group IV $(r=-0.754, p<0.05)$. It was also negatively correlated with HOMA-IR in GDM groups [Group IIIa $(r=-0.717, p<0.05)$ and Group IIIb $(r=-0.871$, $p<0.01)]$ and in Group IV ( $r=-0.695, p<0.05)$. Serum apelin level correlated negatively with TC and LDL in Group IIIb ( $r=-0.845, p<0.01$ and $r=$ $-0.776, p<0.05$ respectively) and Group IV ( $r=$ $-0.736, p<0.05$ and $r=-0.709, p<0.05$ respectively) Apelin levels correlated negatively with TNF $\alpha$ in GDM groups [Group IIIa $(r=0.691, p<0.05)$ and Group IIIb $(r=-0.702, p<0.05)]$ and in Group IV $(r=-0.721, p<0.05)$. Apelin levels didn't correlate with BMI, serum insulin or CRP in all groups (Table 2).

Table (1): Serum level of measured biological parameters in all studied groups.

\begin{tabular}{|c|c|c|c|c|c|c|}
\hline $\begin{array}{l}\text { Groups } \\
\text { Parameters }\end{array}$ & GI & G IIa & G IIb & G IIIa & G IIIb & G IV \\
\hline $\mathrm{BMI}\left(\mathrm{g} / \mathrm{cm}^{2}\right)$ & $0.52 \pm 0.1$ & $0.67 \pm 0.12$ & $0.79 \pm 0.11 * \mathbf{a}, \mathbf{b}$ & $0.84 \pm 0.18$ a'b & $0.96 \pm 0.4^{* a^{\prime} \mathbf{a}^{\prime} \mathbf{b}^{\prime} \mathbf{c}^{\prime} \mathbf{d}}$ & $0.87 \pm 0.09 \%$ \\
\hline Apelin (ng/ml) & $4.62 \pm 0.63$ & $5.29 \pm 0.42^{*} \mathrm{a}$ & $3.97 \pm 0.52^{*} \mathbf{a}^{\prime} \mathbf{b}$ & $4.76 \pm 0.51 * \mathbf{b}, \mathbf{c}$ & $2.9 \pm 0.744^{*} \mathbf{a}^{\prime} \mathbf{b}^{\prime} \mathbf{c}^{\prime} \mathbf{d}$ & $3.45 \pm 0.51 * \mathbf{a}, \mathbf{b}, \mathbf{c}, \mathbf{d}, \mathbf{e}$ \\
\hline Glucose (mg/dl) & $100.8 \pm 6.3$ & $85.8 \pm 4.5^{*} \mathbf{a}$ & $74.6 \pm 9.86^{*} \mathbf{a}^{\prime} \mathbf{b}$ & $143.9 \pm 11_{*} .6^{*} \mathbf{a}^{\prime} \mathbf{b} \mathbf{b}^{\prime} \mathbf{c}$ & $173.5 \pm 15.3^{*} \mathbf{a}^{\prime} \mathbf{b} \mathbf{c}^{\prime} \mathbf{c} \mathbf{d}$ & $164.8 \pm 9.6^{*} \mathbf{a}^{\prime} \mathbf{b}^{\prime} \mathbf{c}^{\prime} \mathbf{d}^{\prime} \mathbf{e}$ \\
\hline Insulin ( & $17.53 \pm 6.6$ & $25.7 \pm 4.8^{*} \mathbf{a}$ & $37.4 \pm 4.7^{\prime} \mathbf{a} \cdot \mathbf{b}$ & $36.7 \pm 5.2^{*} \mathbf{a}^{\mathrm{a}} \mathbf{b}$ & $51.6 \pm 3.7^{*} \mathbf{a}^{\prime} \mathbf{b}^{\prime} \mathbf{c}^{\prime} \mathbf{d}$ & $48.7 \pm 4.5^{*} \mathbf{a}^{\prime} \mathbf{b}^{\prime} \mathbf{c}^{\prime} \mathbf{d}$ \\
\hline HOMA-IR & $4.36 \pm 0.3$ & $5.44 \pm 0.6$ & $6.9 \pm 0.4^{\prime} \mathbf{a}^{\prime} \mathbf{b}$ & $13.03 \pm 0.23 * \mathbf{a}, \mathbf{b}, \mathbf{c}$ & $22.1 \pm 1.7 \mathbf{a}^{\prime} \mathbf{b}^{\prime} \mathbf{c}^{\prime} \mathbf{d}$ & $19.8 \pm 1.05{ }^{*} \mathbf{a}^{\prime} \mathbf{b}^{\prime} \mathbf{c}^{\mathbf{c}} \mathbf{d} \mathbf{e}$ \\
\hline $\mathrm{TC}(\mathrm{mg} / \mathrm{dl})$ & $122.9 \pm 10.7$ & $170.5 \pm 11.16^{*} \mathrm{a}$ & $218 \pm 13.1^{*} \mathbf{a} \cdot \mathbf{b}$ & $254 \pm 6.7^{*} \mathbf{a}^{\prime} \mathbf{b} \mathbf{c}^{\prime} \mathbf{c}$ & $298.6 \pm 14.1 * \mathbf{a}, \mathbf{b}, \mathbf{c}, \mathbf{d}$ & $244 \pm 11.8^{* \mathbf{a}, \mathbf{b}, \mathbf{c}, \mathbf{e}}$ \\
\hline $\mathrm{TG}(\mathrm{mg} / \mathrm{dl})$ & $120 \pm 9.5$ & $184.2 \pm 11.4 * a$ & $284.4 \pm 8.6^{*} \mathbf{a}^{\prime} \mathbf{b}$ & $332.6 \pm 12.4^{*} \mathbf{a}^{\prime} \mathbf{b} \mathbf{c}^{\prime}$ & $384 \pm 19.5 * a^{*} \mathbf{y}^{\prime} \mathbf{c}^{\prime} \mathbf{d}$ & $376.2 \pm 15.6^{*} \mathbf{a}^{\prime} \mathbf{b}^{\prime} \mathbf{c}^{\prime} \mathbf{d}$ \\
\hline HDL (mg/dl) & $33.7 \pm 2.1$ & $45.3 \pm 2.6^{*} \mathrm{a}$ & $53.5 \pm 4.8$ * a'b & $44 \pm 3.1 * a^{*}$ & $36.4 \pm 2.4{ }^{*} \mathbf{b}^{\prime} \mathbf{c}^{\prime} \mathbf{d}$ & $34.4 \pm 6.5$ 'b'c'd \\
\hline LDL (mg/dl) & $65.2 \pm 7.1$ & $88.4 \pm 5.5^{*} \mathbf{a}$ & $107.7 \pm 8.6_{*}^{*} \mathbf{a}^{\prime} \mathbf{b}$ & $151.5 \pm 18_{*} 1^{*}$ a,b,c & $185.4 \pm 12.4{ }^{*} \mathbf{a}^{\prime} \mathbf{b}^{\prime} \mathbf{c}^{\prime} \mathbf{d}$ & $161.9 \pm 16.8_{*}^{*} \mathbf{a}^{\prime} \mathbf{b}^{\prime} \mathbf{c}^{\prime} \mathbf{e}$ \\
\hline CRP (mg/ml) & $0.43 \pm 0.06$ & $0.69 \pm 0.11$ & $0.89 \pm 0.09 * a$ & $1.3 \pm 0.44^{*} \mathbf{a}^{\mathbf{a}} \mathbf{b}$ & $1.8 \pm 0.51$ a'b'c'd & $1.7 \pm 0.36^{*} \mathbf{a} \cdot \mathbf{b}^{\prime} \mathbf{c}^{\prime} \mathbf{d}$ \\
\hline $\mathrm{TNF} \alpha(\mathrm{pg} / \mathrm{ml})$ & $132.2 \pm 16.3$ & $178 \pm 8.9^{*} \mathbf{a}$ & $212 \pm 18.6^{*} \mathbf{a} \cdot \mathbf{b}$ & $302 \pm 18.6^{*} \mathbf{a}^{\prime} \mathbf{b} \cdot \mathbf{c}$ & $383.4 \pm 12.2^{*} \mathbf{a}^{\prime} \mathbf{b}^{\prime} \mathbf{c}^{\prime} \mathbf{d}$ & $342 \pm 19.2 * \mathbf{a}, \mathbf{b}, \mathbf{c}, \mathbf{d}, \mathbf{e}$ \\
\hline
\end{tabular}

*: Significant $(p<0.05)$

a: Versus (I). b: Versus (IIa).

c: Versus (IIb). d: Versus (IIIa)

e: Versus (IIIb) 
Table (2): Correlation between apelin and measured biological parameters.

\begin{tabular}{|c|c|c|c|c|c|c|}
\hline $\begin{array}{l}\text { Groups } \\
\text { Parameters }\end{array}$ & GI & G IIa & G IIb & G IIIa & G IIIb & G IV \\
\hline BMI $\left(\mathrm{g} / \mathrm{cm}^{2}\right)$ & 0.195 & 0.070 & 0.203 & 0.084 & 0.097 & 0.146 \\
\hline Glucose $(\mathrm{mg} / \mathrm{dL})$ & 0.285 & 0.179 & -0.106 & $-0.692 *$ & $-0.703 *$ & $-0.754 *$ \\
\hline Insulin ( & 0.171 & 0.265 & 0.210 & 0.218 & 0.023 & 0.324 \\
\hline HOMA-IR & -0.120 & -0.070 & -0.140 & $-0.717^{*}$ & $-0.871 * *$ & $-0.695 *$ \\
\hline $\mathrm{TC}(\mathrm{mg} / \mathrm{dl})$ & 0.026 & 0.175 & -0.049 & -0.133 & $-0.845^{* *}$ & $-0.736^{*}$ \\
\hline TG (mg/dl) & 0.187 & 0.076 & 0.119 & 0.064 & 0.058 & 0.172 \\
\hline HDL (mg/dl) & 0.042 & 0.196 & -0.088 & 0.156 & 0.057 & 0.140 \\
\hline LDL (mg/dl) & 0.025 & 0.142 & 0.081 & -0.135 & $-0.776^{*}$ & $-0.709 *$ \\
\hline CRP (Ug/dl) & 0.071 & 0.157 & 0.148 & 0.098 & -0.125 & -0.216 \\
\hline $\mathrm{TNF}_{0 \mathrm{c}}(\mathrm{pg} / \mathrm{ml})$ & 0.098 & 0.356 & 0.243 & $-0.691 *$ & $-0.702 *$ & $-0.721 *$ \\
\hline
\end{tabular}

Estimated Area Under the Curve (AUC) of Oral Glucose Tolerance Test (OGTT) revealed significant increase in AUC in GDM Group (IIIb) compared to normal pregnant Group (IIb) $(p<0.001)$. Vitamin D3 supplementation induced significant decrease in AUC in Group IV compared to Group IIIb $(p<0.05)$ Figs. $(1,2)$.

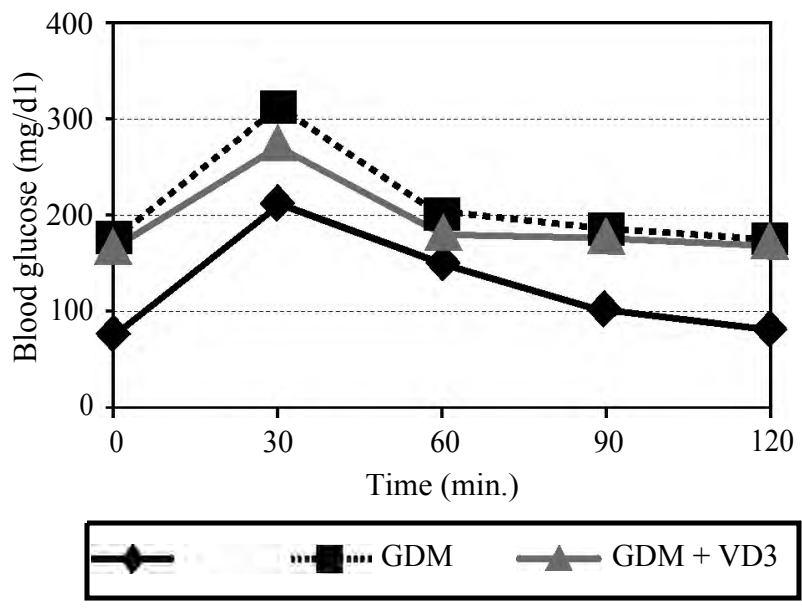

Fig. (1): Oral Glucose Tolerance Test (OGTT) on day 18. NP (Group IIb); GDM (Group IIIb) and GDM + VD3 (Group IV).

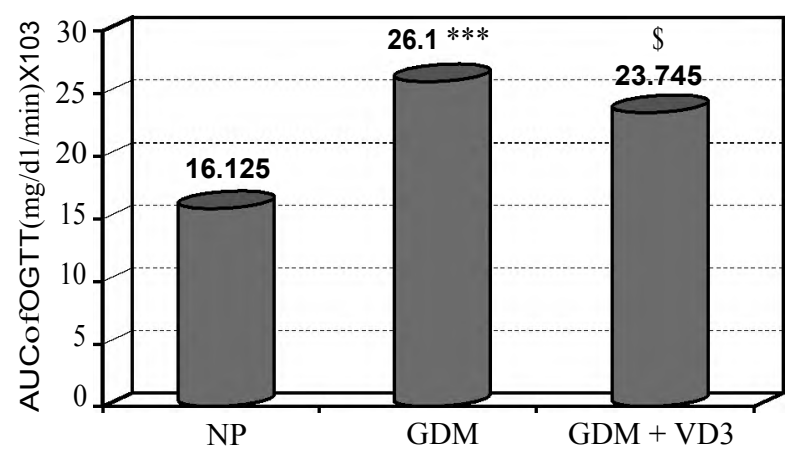

Fig. (2): Estimated Area Under the Curve (AUC) of OGTT NP (Group IIb); GDM (Group IIIb) and GDM + VD3 (Group IV).

$* * *$ : Significant versus NP group $(p<0.001)$.

$\$$ : Significant versus GDM group $(p<0.05)$

\section{Discussion}

The results revealed a significant increase in serum aplelin in mid gestation (day 11), while in late pregnancy (day 19), serum apelin levels showed a significant decrease relative to non-pregnant levels. This pattern of change in serum apelin level in pregnancy was previously reported by Mayeur et al., [40] who found a gradual increase in rat maternal apelin levels from day 7 to day 17 then decrease at term. Also Hanssens et al., [29] found an elevation in mice maternal apelinemia on day 6.5 and day 12.5, while a decrease was found on day 18.5. Similar to our results, Van Mieghem et al., [10] reported a 50\% drop in rat plasma apelin levels in late gestation but opposite to our results, they found that, serum apelin levels at day 7 and day 14 were within non-pregnant range. In human pregnancy, the study of Kourtis et al., [41] showed a reduction in serum apelin level in normal pregnant females examined between the 24 th to the $28^{\text {th }}$ week of gestation.

The increase in serum apelin in mid-pregnancy might be a result of the increase in serum insulin as shown in our results. Pregnancy is normally associated with a state of hyper-insulinemia $[8]$ and apelin expression and release was frequently linked to insulin both in vivo and in vitro studies. In mice, apelin expression in adipocytes was positively correlated with insulin plasma levels both in fasting and after re-feeding $[\mathbf{4 2 , 4 3 ]}$. Moreover, expression of adipocyte apelin mRNA was decreased in streptozotocin induced insulin deficient mice $[42,44]$, while insulin treatment in cultured adipocytes increased apelin expression and secretion [5]. However, in late pregnancy groups (day 19), apelin level decreased in spite of the greater increase in insulin levels relative to mid pregnancy values this might be attributed to insulin resistance during pregnancy which increases as pregnancy advances [8] as indicated in our results by the 
significant increase in HOMA-IR in late pregnancy group relative to both mid pregnancy and nonpregnant group. Moreover, pregnancy induce changes in number and/or function of insulin receptors [45] which can cause a change in insulin effect on apelin secretion as it was reported that, in a rat ex-vivo study, at day 10 of gestation, the sensitivity of muscle and adipose tissue to insulin action markedly increase due to an elevation in the amount, gene expression and phosphorylation of insulin receptor relative to late gestation (days 15-20) [45] which might have a role in the increase of apelin level in day 11 group and its decrease in day 19 group. Also, absence of significant correlation between apelin and insulin in our results which was consistent with previous findings [41] indicates that, factors other than insulin are more involved in apelin regulation during pregnancy.

The increase in adipose tissue mass during pregnancy [46] can also be a source of the increased apelin in mid-gestation as apelin and its receptors were reported to be produced and secreted by mouse, human and rat adipose tissue $[4 \mathbf{4 2 , 4 3 , 4 7 ]}$. In late pregnancy, maternal adipose tissue mass decrease in spite of the overall weight gain $[49,50]$ which might contribute to the reduction of apelin level in late gestation. It should be mentioned that, our results revealed non-significant correlation between apelin and BMI in all groups. Part of pregnancy induced weight gain is attributable to placenta, foetus, amniotic fluid and elevated blood volume and the remaining weight gain is due to accumulation of maternal Adipose Tissue (AT) needed to support foetal growth and subsequent nutritional demands of lactation [46] making it difficult to determine the correlation between apelin and BMI during pregnancy. Moreover, in most researches, apelin did not correlate with BMI, leading to the speculation that, obesity is not the main determinant of increased apelin concentration $[\mathbf{1 , 1 3 , 5 1 ]}$. In the same context, Telejko et al., [13] found that, apelin mRNA expression was 10 fold higher in the placenta than in visceral or subcutaneous adipose tissue of pregnant female indicating greater role for the placenta in apelin expression during pregnancy than in adipose tissue. In fact, placental apelin mRNA expression and release was detected in human [13] and rat [40] placental tissues. In the study of Hanssens et al., [29], significant amounts of aplein were released from mouse placental tissue at day 12.5 and day 18.5 of gestation. Mayeur and his team [40] studied the ex-vivo rat placental aplein release in $24 \mathrm{~h}$ and demonstrated a two fold increase in aplein secretion at day 17 relative to day 21 which matches with the changes in serum apelin level found in our study.
However, Van Mieghem et al., [10] found that, aplein expression was detected in the placenta and mesometrial tissue during pregnancy and it was increased at term in mammary glands 200 times the non-pregnant level. Moreover, they found no significant change in the expression of apelin mRNA in non-reproductive tissues in late gestation relative to non-pregnant values which indicates that the drop in apelin level in late gestation is not due to a decrease in apelin production and they linked the decrease in apelin level in late gestation to an increase in placental clearance of apelin due to significant increase in the expression of ACE2 mRNA in rat placental tissue in day 22 but not in day 16 of gestation. ACE2 is the angiotensinconverting enzyme-related carboxypeptidase- 2 which is the main enzyme responsible for degradation of apelin and these results were proved by the increase in apelin levels after experimental reduction of fetoplacental unit [10]. In addition, Joyner et al., [52] found an increase in renal levels of ACE2 in Sprague-Dawley rats from middle to late stages of pregnancy in association with increased renal blood flow in pregnancy which may participate in increasing renal clearance of apelin and so decrease its serum level in late gestation.

Apelin level in late gestation was reported to be six folds higher in foetal than in maternal serum in mice [29]. This variation might be linked to a difference in the site of insulin stimulated apelin secretion. Insulin increased aplein release from human placental tissue [14] as was previously described in adipose tissue [42,43,47]. It is interesting that, distribution of insulin receptors in the fetoplacental interface changes from early and mid to late pregnancy being higher in the maternal side (placenta) in early pregnancy, which affects mainly maternal circulation, then shifted to the foetal side in late gestation (endothelium), which affects mainly foetal circulation [53], this can help to explain the increase in apelin level in maternal blood in mid-gestation then its decrease in late gestation in maternal circulation meanwhile it increases in foetal circulation which might be attributed to a spatiotemporal change in insulin stimulated apelin secretion [53].

Finally, Apelin binds to the orphan receptors APJ which have closest identity to Angiotensin II receptor type 1 (AT1R). However, aplein has cardiovascular and metabolic effects opposite to angiotensin II (Ang II). Renin Angiotensin System (RAS) was reported to inhibit apelin expression as long-term treatment of cultured 3T3-L1 cells with Ang II induced down-regulation of Apelin expressions. Blocking RAS in 3T3-L1 adipocytes 
increased apelin expression and secretion [54]. In normal pregnancy, up-regulation of different components of RAS was detected including angiotensinogen, Ang II, renin and aldosterone. However, there is a decline in Ang II sensitivity as pregnant women are twice more resistant to the effect of Ang II due to increased progesterone and prostacyclins levels [55] and to some extent due to inactivation of AT $1 \mathrm{R}$ during pregnancy [56]. Placental apelin release from human placental tissue was reported to decrease by Ang II [14]. However, the increased Ang II in pregnancy is unable to inhibit apelin expression and secretion owing to Ang II resistance.

We studied serum apelin level in gestational diabetic rats. To obtain a rat model of gestational diabetes, numerous studies used streptozotocin to induce B cell dysfunction. However, this technique results in severe hyperglycemia, decrease in insulin secretion and low fetal weight [21] in contrast to the usual criteria of human gestational diabetes which include mild to moderate hyperglycemia, hyperinsulinemia and increased birth weight [24] Others used a rat model of high fat high sucrose diet to induced obesity and obtain a rat model of gestational diabetes closer to human gestational diabetes [22] and so, this model was chosen for our study.

In gestational diabetic group, serum apelin levels were significantly lower than normal pregnant levels both at day 11 and day 19. Only limited studies about apelin level in gestational diabetes are available with conflicting results. Similar to our results, Hanssens [14] showed a reduction in maternal apelin level in obese pregnant women with and without gestational diabetes relative to their normal pregnant control. Ayden [57] also found lower concentrations of apelin in the serum and milk of gestational diabetic women. Moreover, Akinci et al., [58] found a decrease in circulating apelin in women with previous gestational diabetes which was linked to an increase in cardiovascular risk factors. In contrast, Aslan et al., [12] found an increase in maternal apelin level in gestational diabetic women, while Telejko et al., [13] found no significant difference in apelin level in gestational diabetic women relative to normal controls either in the third trimester or at term. In Aslan et al's study [12], apelin was measured in maternal serum during labour, after delivery of the baby and before delivery of the placenta. Such time of stress may affect apelin level as apelin is highly expressed in the hypothalamus, PVN and SON nuclei and was reported to be involved in stress responses [1] These findings are to be considered as a possible cause of the non-matching between their results and ours. While in Telejko et al., [13] study, apelin level in gestational diabetic women in 3 rd trimester tends to be lower than normal pregnant control as for our results but it was statistically insignificant.

Gestational diabetes is identified as mild to moderate hyperglycaemia that is first diagnosed during pregnancy and so it can reflect numerous pathological changes similar to those involved in early stages of type 2 diabetes [59]. Ren and his team [60] found a significant decrease in apelin level in newly diagnosed type 2 diabetic patients. Similar results were also reported by Erdem et al., [7] who found a decrease in apelin level in newly diagnosed and untreated type 2 diabetic patients. In contrast other investigators found an increase in apelin level in type 2 diabetic patients either with or without severe obesity $[\mathbf{4 2 , 6 1 , 6 2}]$, however, in most of these studies, patients were under treatment and it was reported that, treatment with antidiabetic drugs for 14 days improved glycaemic profile and induced an increase in apelin level [63] Some authors explained this conflict by suggesting that, the increase in apelin level in type 2 diabetes was an attempt of the body to compensate for insulin resistance found in these chronic cases when the full picture of disease is found on the long term but not in early stages of the disease [64] which is clinically closer to gestational diabetes. In support with this hypothesis, previous studies reported non-significant change in apelin level in response to acute changes in glucose or insulin level in human [64] or mouse [42]

This reduction in apelin level in gestational diabetes might be due to increased insulin resistance as shown in our results by the significant increase in HOMA-IR which correlated negatively with apelin in gestational diabetic rats both at day 11 and day 19 groups relative to gestational age matched normal pregnant rats which in turn can decrease insulin stimulated apelin secretion. In line with this, Chang et al., [65] and Choi et al., [66] found a significant decrease in serum apelin level in patients with poly cystic ovary in whom insulin resistance is a characteristic finding. In fact, normal pregnancy is associated with an increase in insulin secretion to compensate for the increase in insulin resistance and this adaptive response was attributed to hypertrophy of pancreatic 3 cell with an increase in insulin secretion rates (ISR) induced by placental hormones [8]. In gestational diabetic women, greater insulin resistance was reported relative to normal pregnant women but pancreatic $\beta$ cells fail to compensate for this increase in insulin resistance especially in late 
gestation [59]. Insulin secretion rates were found lower in gestational diabetes relative to normal pregnancy and also relative to severity of insulin resistance [67]. After delivery, insulin secretion rates were found normal in GDM but insulin resistance remain higher than normal which indicated a large defect in $\beta$ cell function that is manifested during pregnancy and persists after delivery [67].

A decrease in placental release of apelin in GDM might also be a contributing factor. In high fat diet mouse placenta ex-vivo study, a drastic decrease in apelin release was noticed at day 18.5 of gestation in spite of the significant increase in apelin mRNA expression. The authors suggested a defect in apelin post-translation or release [29] In another human placenta ex-vivo study, a reduction in apelin release was found in the placentae of both obese and gestational diabetic women [14]

Apelin expression and secretion was induced in human adipocytes by overexpression of PPAR $\gamma$ (peroxisome proliferator-activated receptor gamma) coactivator-1 $\alpha(\mathrm{PGC} 1 \alpha)$ which is a main regulator of energy homeostasis [68]. PPAR $\gamma$ mRNA and protein concentration were found lower in term placentas of gestational diabetic women [69] which may share in the reduced apelin level observed in gestational diabetic rats.

Renin Angiotensin System (RAS) plays a role in glycaemic control and the pathogenesis of insulin resistance in gestational diabetes [70]. In newly diagnosed diabetes with moderate hyperglycaemia and no glycosuria as the case in gestational diabetes, an increase in plasma renin activity, local and circulating RAS was reported [71,72]. This increase can induce a reduction in apelin level as was previously mentioned.

In Group IV, Vitamin D3 induced a significant decrease in blood glucose, HOMA-IR, TC, LDL and TNF $\alpha$. An association between Vitamin D deficiency and GDM was reported by several studies $[11,15,16]$. However, the effect of Vitamin D supplementation on metabolic state and insulin sensitivity was conflicting. While some investigators reported significant decrease in insulin resistance [17], others reported no effect [20] but the studies showed marked variation in dosage, timing and duration of treatment [11].

Vitamin D3 supplementation in Group IV induced significant increase in apelin level relative to GDM group (Group IIIb). The increase in apelin level by the effect of Vitamin D3 was previously referred to in the study of Teng et al., [73] who found $91.6 \%$ increase in apelin mRNA after ad- ministration of high dose of Vitamin D3 in rats. This increase might be attributed to an improvement of insulin sensitivity as proved by the significant decrease in HOMA-IR which in turn can increase insulin stimulated apelin secretion. Vitamin D was reported to counteract free fatty acids induced insulin resistance [74], increase insulin receptor expression and improves insulin mediated glucose transport in vitro [75]. Also Vitamin D can increase insulin synthesis from pancreatic $\beta$ cells [756] and a Vitamin D response element was found on insulin gene [77]

In late gestation (day 19), a significant increase in TC, TG, LDL and significant decrease in HDL was found in GDM group compared to normal pregnant group. In Vitamin D3 treated group, a significant decrease in TC and LDL was found compared to gestational diabetic group. Moreover, TC and LDL level correlated negatively with serum apelin in gestational diabetic group and in vitamin D3 treated group. Dyslipidaemia is a normal finding in pregnancy to increase fatty acid utilization for maternal energy production and increase the availability of glucose to the foetus. This dyslipidaemia markedly increase in gestational diabetes and may play a role in insulin resistance [8]. Apelin inhibits lipolysis in 3T3-L1 adipocytes and its deficiency in apelin knockout mice resulted in an increase in free fatty acids which was reversed by exogenous apelin injection [78]. Apelin level was reported to decrease in dyslipidaemia, while lowering LDL cholesterol either by therapeutic life style or statin treatment was accompanied by an increase in apelin level in association with a decrease in HOMA-IR [79] which is consistent with our results.

Moreover, in GDM group we found a significant increase in TNF $\alpha$ relative to normal pregnant levels. The elevated levels of TNF $\alpha$ play a major role in the defect of insulin signalling cascade which accounts for the increase in insulin resistance in GDM [8]. Treatment with Vitamin D3 in Group IV induced significant decrease in TNF $\alpha$ levels associated with a decrease in HOMA-IR and both were negatively correlated with apelin levels and the improved insulin sensitivity can then increase apelin secretion. In line with this finding, Vitamin $\mathrm{D}$ was previously found to cause significant reduction in TNF $\alpha$ in cultured human monocytes [80].

The increase in apelin in Vitamin D treated group might also be caused by the suppressive effect of Vitamin D on renin angiotensin (RAS) system which was reported to decrease apelin secretion [54] as it was found that treatment of mice with Vitamin D3 caused reduction in renin expres- 
sion $[\mathbf{8 1 , 8 2}$, while in Vitamin D receptor null mice, a significant increase in renin and angiotensin II was reported [81]. Another explanation is the effect of Vitamin D on peroxisome proliferator activator receptor-y (PPAR y) [83] . Vitamin D directly increases the transcription of PPAR y which was reported to increase apelin secretion [68] .

\section{Conclusion:}

In normal pregnant rats, serum apelin level increased in mid-gestation then decrease at term. Gestational diabetes induced significant decrease in serum apelin level in pregnant rats compared to normal pregnant gestational age matched control indicating that apelin level in pregnancy is altered by glycaemic state. Whether the decrease in apelin is a cause or a result of increased insulin resistance in gestational diabetes, needs further investigation. Vitamin D3 supplementation in gestational diabetic rats induced significant improvement of insulin sensitivity and this was associated with significant increase in apelin level suggesting a role for apelin in improvement of insulin sensitivity and highlight apelin and Vitamin D3 as potential future therapies for gestational diabetes.

\section{References}

1- O'CARROLL A.M., LOLAIT S.J., HARRIS L.E. and POPE G.R.: The apelin receptor APJ: Journey from an orphan to a multifaceted regulator of homeostasis. Journal of Endocrinology, 219: R13-R35, 2013.

2- KIDOYA H. and TAKAKURA N.: Biology of the apelinAPJ axis in vascular formation. J. Biochem., 152 (2): 125-31, 2012.

3- DRAY C., KNAUF C., DAVIAUD D., WAGET A., BOUCHER J., BULEON M., CANI P.D., ATTANE C., GUIGNE C. and CARPENE C.: Apelin stimulates glucose utilization in normal and obese insulin-resistant mice. Cell Metabolism., 8: 437-45, 2008.

4- ATTANE C., FOUSSAL C., Le GONIDEC S., BENANI A., DAVIAUD D., WANECQ E., GUZMAN-RUIZ R., DRAY C., BEZAIRE V. and RANCOULE C.: Apelin treatment increases complete fatty acid oxidation, mitochondrial oxidative capacity, and biogenesis in muscle of insulin-resistant mice. Diabetes, 61: 310-20, 2012.

5- SORHEDE W.M., MAGNUSSON C. and AHREN B.: The apj receptor is expressed in pancreatic islets and its ligand, apelin, inhibits insulin secretion in mice. Regulatory Peptides., 131: 12-7, 2005.

6- CAVALLO M.G., SENTINELLI F., BARCHETTA I., COSTANTINO C., INCANI M., PERRA L., CAPOCCIA D., ROMEO S., COSSU E. and LEONETTI F.: Altered glucose homeostasis is associated with increased serum apelin levels in type 2 diabetes mellitus. PLoS ONE., 7: e51236, 2012.

7- ERDEM G., DOGRU T., TASCI I., SONMEZ A. and TAPAN S.: Low plasma apelin levels in newly diagnosed type 2 diabetes mellitus. Experimental and Clinical Endocrinology \& Diabetes, 116: 289-92, 2008.

8- BARBOUR L.A., MCCURDY C.E., HERNANDEZ T.L., KIRWAN J.P., CATALANO P.M. and FRIEDMAN J.E.: Cellular Mechanisms for Insulin Resistance in Normal Pregnancy and Gestational Diabetes. Diabetes Care, 30 (2): S112-S119, 2007.

9- COBELliS L., De FALCO M., MASTROGIACOMO A., GIRALDI D., DATTILO D. and SCAFFA C.: Modulation of apelin and APJ receptor in normal and preeclampsiacomplicated placentas. Histol. Histopathol., 22: 1e8, 2007.

10- VAN MIEGHEM T., VAN BREE R., VAN HERCK E., PIJNENBORG R., DEPREST J. and VERHAEGHE J.: Maternal Apelin Physiology during Rat Pregnancy: The Role of the Placenta. Placenta., 31: 725e-30, 2010.

11-CHO G.J., HONG S.C. and OH M.J.: Vitamin D deficiency in gestational diabetes mellitus and the role of the placenta. Am. J. Obstet. Gynecol., 209: 560.e1-8, 2013.

12- ASLAN M., CELIK O., CELIK N., TURKCUOGLU I., YILMAZ E., KARAER A., SIMSEK Y., CELIK E. and AYDIN S.: Cord blood nesfatin-1 and apelin-36 levels in gestational diabetes Mellitus. Endocrine., 41: 424-9, 2012.

13- TELEJKO B., KUZMICKI M., WAWRUSIEWICZKURYLONEK N., SZAMATOWICZ J., NIKOLAJUK A., ZONENBERG A., ZWIERZ-GUGALA D., JELSKI W., LAUDANSKI P., WILCZYNSKI J., KRETOWSKI A. and GORSKA M.: Plasma apelin levels and apelin/APJ mRNA expression in patients with gestational diabetes mellitus. Diabet. Res. Clin. Pract., 87 (2): 176-83, 2010.

14- HANSSENS S.: Maternal obesity and gestational diabetes mellitus alter the apelinergic system during pregnancy. American Journal of Obstetrics \& Gynecology, 1: S369S370, 2018 .

15- MAGHBOOLI Z., HOSSEIN-NEZHAD A., KARIMI F., SHAFAEI A.R. and LARIJANI B.: Correlation between vitamin D3 deficiency and insulin resistance in pregnancy. Diabetes Metab. Res. Rev., 24: 27-32, 2008.

16- CLIFTON-BLIGH R.J., MCELDUFF P. and MCELDUFF A: Maternal Vitamin D deficiency, ethnicity and gestational diabetes. Diabet. Med., 25: 678-84, 2008.

17- ASEMI Z., HASHEMI T., KARAMALI M., SAMIMI M., and ESMAILLZADEH A.: Effects of Vitamin D supplementation on glucose metabolism, lipid concentrations, inflammation, and oxidative stress in gestational diabetes: A double-blind randomized controlled clinical trial. Am. J. Clin. Nutr., 98: 1425-32, 2013.

18- BAKER A.M., HAERI S., CAMARGO C.A. Jr., STUEBE A.M. and BOGGESS K.A.: First-trimester maternal vitamin D status and risk for gestational diabetes (GDM) a nested case-control study. Diabetes Metab. Res. Rev., 28: 164-8, 2012.

19- MAKGOBA M., NELSON S.M., SAVVIDOU M., MESSOW C.M., NICOLAIDES K. and SATTAR N: First trimester circulating 25-hydroxyvitamin D levels and development of gestational diabetes mellitus. Diabetes Care, 34: 1091-3, 2011.

20- SALEHPOUR A., SHIDFAR F., HOSSEINPANAH F., VAFA M., RAZAGHI M. and AMIRI F.: Does vitamin D3 supplementation improve glucose homeostasis in overweight or obese women? A double-blind, randomized, 
placebo controlled clinical trial. Diabet. Med., 30 (12): 1477-81, 2013.

21- ABDEL-REHEIM E.S., ABD-ELMONEIM A.A., and HOSNI A.A.: Fatty-sucrosed diet/minimal dose of streptozotocin-treated rat: A novel model of gestational diabetes mellitus, metabolic and inflammatory insight. Journal of Diabetes \& Metabolism, 5: 430-8, 2014.

22- PEREIRA T., FONSECA M.A., CAMPBELL K.E., MOYCE B.L., COLE L.K., HATCH G.M., DOUCETTE C.A., KLEIN J.6, ALIANI M. and DOLINSKY V.W.: Maternal obesity characterized by gestational diabetes increases the susceptibility of rat offspring to hepatic steatosis via a disrupted liver metabolome. J. Physiol., 593 (14): 3181-97, 2015.

23- NING C., LIU L., LV G.2, YANG Y., ZHANG Y., YU R.1, WANG Y. and ZHU J.: Lipid metabolism and inflammation modulated by Vitamin $\mathrm{D}$ in liver of diabetic rats. Lipids in Health and Disease, 14: 31, 2015.

24- American Diabete Association: 2. Classification and Diagnosis of Diabetes. Diabetes Care, 38 (1): S8-S16, 2015.

25- MEHTA A.A., AGRAWAL A.D., APPANNA V. and CHAUDAGAR K.K.: Vitamin D improves corticosteroid efficacy and attenuates its side-effects in an animal model of asthma. Can. J. Physiol. Pharmacol., 3: 1-9, 2014.

26- MARCONDES F.K., BIANCHI F.J. and TANNO A.P.: Determination of the estrous cycle phases of rats: Some helpful considerations. Brazilian Journal of Biology, 62 (4): 609-14, 2002.

27- KLUKOVITS A., RÓBERT G., PÉTER S. and GÁBOR J.: Functional and histochemical characterization of a uterine adrenergic denervation process in pregnant rats. Biol. Reprod., 67 (3): 1013-7, 2002.

28- HEGAB I.I.: Ameliorative effect of apelin on streptozotocin-induced diabetes and its associated cardiac hypertrophy. Alexandria Journal of Medicine, 54: 119-27, 2018.

29- HANSSENS S., MARX-DESEURE A., LECOUTRE S., BUTRUILLE L., FOURNEL A., KNAUF C., BESENGEZ C., BRETON C., STORME L., DERUELLE P. and LESAGE J.: Maternal obesity alters the apelinergic system at the feto-maternal Interface. Placenta, 39: 41e44, 2016.

30- NOVELLI E.L., DINIZ Y.S., GALHARDI C.M., EBAID G.M., RODRIGUES H.G., MANI F., FERNANDES A.A., CICOGNA A.C. and NOVELLIFILHO J.L.: Anthropometrical parameters and markers of obesity in rats., Lab. Anim., 41 (1): 111-9, 2007.

31- TIETZ N.W.: Clinical guide to laboratory tests. Pbl. W.B. Saunders, Co., Philadelphia, PP. 509-12, 1995.

32- TEMPLE R.C., CLARK P.M. and HALES C.N.: Measurement of insulin secretion in typ9e II diabetes: Problems and pitfalls. Diabetic Medicine, 9 (6): 503-12, 1992.

33- MATTHEWS D.R., HOSKER J.P., RUDENSKI A.S., NAYLOR B.A. and TURNER R.C.: Homeostasis model assessment: insulin resistance and beta-cell function from fasting plasma glucose and insulin concentrations in man. Diabetologia, 28 (7): 412-9, 1985.

34- SUN G., BISHOP J., KHALILI S., VASDEV S., GILL V., PACE D., FITZPATRICK D., RANDELL E., YA-XIE G. and ZHANG H.: Serum visfatin concentrations are positively correlated with serum triacylglycerols and down-regulated by overfeeding in healthy young men. Am. J. Clin. Nutr., 85: 399-404, 2007.

35- ENGELBERTS I., MÖLLER A., SCHOEN G.J., VAN DER LINDEN C.J. and BUURMAN W.A.: Evaluation of measurement of human TNF in plasma by ELISA. Lymphokine Cytokine Res., 10 (1-2): 69-76, 1991.

36- RIDKER P.M., RIFAI N., PFEFFER M.A., SACKS F.M., MOYE L.A., GOLDMAN S., FLAKER G.C. and BRAUNWALD E.: Inflammation, Pravastatin and the risk of coronary events after myocardial infarction in patients with average cholesterol levels. Circulation, 98 (9): 839-44, 1998.

37- NAITO H.K.: Triglycerides in clinical chemistry: Theory, analysis and correlation. Pbl. KaplanL A and Pesce A.J., U.S.A., PP. 997, 1989.

38- NAUK M., MARZ W. and JARAUSCH J.: Multicenter evaluation of homogenous assay for HDL-Cholesterol without sample pretreatment. Clin. Chem., 43 (9): 1622 9, 1997.

39- FRIEDWALD W.T., LEVY R.I. and FREDRICKSON D.S.: Estimation of the concentration of low-density lipoprotein cholesterol in plasma, without use of the preparative ultracentrifuge. Clin. Chem., 18: 499-502, 1972.

40- MAYEUR S., WATTEZ J.S., LUKASZEWSKI M.A., LECOUTRE S., BUTRUILLE L., DROUGARD A., EBERLE D., BASTIDE B., LABORIE C., STORME L., KNAUF C., VIEAU D., BRETON C., and LESAGE J.: Apelin controls fetal and neonatal glucose homeostasis and is altered by maternal undernutrition. Diabetes, Doi: $10.2337 / \mathrm{db} 15-0228,2015$.

41- KOURTIS A., GKIOMISI A., MOUZAKI M., MAKEDOU K., ANASTASILAKIS A.D., TOULIS K.A., GEROU S., GAVANA E. and AGORASTOS T.: Apelin levels in normal pregnancy Clinical Endocrinology, 75: 367-71, 2011.

42- BOUCHER J., MASRI B., DAVIAUD D., GESTA S., GUIGNE C., MAZZUCOTELLI A., CASTAN-LAURELL I., TACK I., KNIBIEHLER B., CARPENE C., et al.: Apelin, a newly identified adipokine up-regulated by insulin and obesity. Endocrinology, 146: 1764-71, 2005.

43- DRAY C., DEBARD C., JAGER J., DISSE E., DAVIAUD D., MARTIN P., ATTANE C., WANECQ E., GUIGNE C., BOST F., et al.: Apelin and APJ regulation in adipose tissue and skeletal muscle of type 2 diabetic mice and humans. American Journal of Physiology. Endocrinology and Metabolism, 298: E1161-E9, 2010.

44- WEI L., HOU X. and TATEMOTO K.: Regulation of apelin mRNA expression by insulin and glucocorticoids in mouse 3T3-L1 adipocytes. Regulatory Peptides, 132: 27-32, 2005.

45- GONZÁLEZ C.G., ALONSO A., BALBÍN M., DÍAZ F., FERNÁNDEZ S. and PATTERSON A.M.: Effects of pregnancy on insulin receptor in liver, skeletal muscle and adipose tissue of rats. Gynecological Endocrinology, 16 (3): 193-205, 2002.

46- SIMAS T.A.M. and CORVERA S.: The Roles of Adipose Tissue and Inflammation in Gestational Diabetes Mellitus. Intern. Med., S6: S6-010, 2014.

47- KLEINZ M.J., SKEPPER J.N. and DAVENPORT A.P.: Immunocytochemical localisation of the apelin receptor, 
APJ, to human cardiomyocytes, vascular smooth muscle and endothelial cells. Regulatory Peptides, 126: 233-40, 2005.

48- CATALANO P.M.: Obesity and pregnancy: The propagation of a vicious cicle. J. Clin. Endocrinol. Metabol., 88: 3505-6, 2003.

49- CATALANO P.M., WONG W.W., DRAGO N.M. and AMINI S.B.: Estimating body composition in late gestation: A new hydration constant for body density and total body water. American Journal of Physiology. Endocrinology and Metabolism, 268: E153-E8, 1995.

50- SEWELL M.F., HUSTON-PRESLEY L., AMINI S. and CATALANO P.M.: Body mass index, a true indicator of body fat in obese gravidas. Journal of Reproductive Medicine, 52: 907-11, 2007.

51- MALAMITSI-PUCHNER A., GOURGIOTIS D., BOUTSIKOU M., et al.: Circulating apelin concentrations in mother/infant pairs at term. Acta Paediatrica, 96: 17514, 2007.

52- JOYNER J., NEVES L.A., GRANGER J.P., ALEXANDER B.T., MERRILL D.C., CHAPPELL M.C., FERRARIO C.M., DAVIS W.P. and BROSNIHAN K.B.: Temporalspatial expression of angiotensin-(1-7) and angiotensin converting enzyme 2 in the kidney of normal and hypertensive pregnant rats. Am. J. Physiol. Regul. Integr. Comp. Physiol., 239: R169-R77, 2007.

53- DESOYE G. and De MOUZON S.H.: The Human Placenta in Gestational Diabetes Mellitus, The insulin and cytokine network. Diabetes Care, 30 (2): S120-S6, 2007.

54- HUNG W.W., HSIEH T.J., LIN T., CHOU P.C. and HSIAO P.J., et al.: Blockade of the Renin-Angiotensin System Ameliorates Apelin Production in 3T3-L1 Adipocytes. Cardiovascular Drugs and Therapy, 25 (1): 3-12, 2010.

55- RODRIGUEZ M., MORENO J. and HASBUN J.: RAS in Pregnancy and Preeclampsia and Eclampsia. International Journal of Hypertension, doi: 10.1155/2012/739274, 2012.

56- ABDALLA S., LOTHER H., EL-MASSIERY A. and QUITTERER U.: Increased AT (1) receptor heterodimers in preeclampsia mediate enhanced angiotensin II responsiveness. Nature Medicine, 7: 1003-9, 2001.

57- AYDIN S.: The presence of the peptides apelin, ghrelin and nesfatin- 1 in the human breast milk, and the lowering of their levels in patients with gestational diabetes mellitus. Peptides, 31 (12): 2236-40, 2010.

58- AKINCI B., CELTIK A., TUNALI S., GENC S., YUKSEL F., SECIL M., OZCAN M.A. and BAYRAKTAR F.: Circulating apelin levels are associated with cardiometabolic risk factors in women with previous gestational diabetes. Arch. Gynecol. Obstet., 289: 787-93, 2014.

59- BUCHANAN T.A., XIANG A.H., KJOS L. and WATANABE R.: What is gestational diabetes? Diabetes Care, 30 (2): S105-S 11, 2007.

60- REN F., ZHANG N., SUN J. and YANG J.: Low Plasma Apelin in Newly Diagnosed Type 2 Diabetes in Chinese People. Diabetes Care, 32 (12): e150, 2009.

61- LI L., YANG G., LI Q., TANG Y., YANG M., YANG H and LI K.: Changes and relations of circulating visfatin, apelin, and resistin levels in normal, impaired glucose tolerance, and type 2 diabetic subjects. Experimental and Clinical Endocrinology \& Diabetes, 114: 544-8, 2006.

62- DAVIAUD D., BOUCHER J., GESTA S., DRAY C., GUIGNE C., QUILLIOT D., AYAV A., ZIEGLER O., CARPENE C., SAULNIER-BLACHE J.S., et al.: TNFa up-regulates apelin expression in human and mouse adipose tissue. FASEB Journal, 20: 1528-30, 2006.

63- KADOGLOU N., TSANIKIDIS H., KAPELOUZOU A., VRABAS I., VITTA I., KARAYANNACOS P., LIAPIS C. and SAILER N.: Effects of rosiglitazone and metformin treatment on apelin, visfatin, and ghrelin levels in patients with type 2 diabetes mellitus. Metabolism: Clinical and experimental, 59: 373-9, 2009.

64- ALEXIADOU K., KOKKINOS A.R, LIATIS S., PERREA D., KATSILAMBROS N. and TENTOLOURIS N.: Differences in plasma apelin and visfatin levels between patients with type 1 diabetes mellitus and healthy subjects and response after acute hyperglycemia and insulin administration. Hormones, 11 (4): 444-50, 2012.

65- CHANG C.Y., TSAI Y.C., LEE C.H., CHAN T.F., WANG S.H. and SU J.H.: Lower serum apelin levels in women with polycystic ovary syndrome. Fertility and Sterility, 95: 2520-3, 2011

66- CHOI Y.S., YANG H.I., CHO S., JUNG J.A., JEON Y.E., KIM H.Y., et al.: Serum asymmetric dimethylarginine, apelin, and tumor necrosis factor-a levels in non-obese women with polycystic ovary syndrome. Steroids, 77 : $1352-8,2012$

67- BUCHANAN T.A.: Pancreatic B-cell defects in gestational diabetes: Implications for the pathogenesis and prevention of type 2 diabetes. J. Clin. Endocrinol. Metab., 86: 98993, 2001.

68- MAZZUCOTELLI A., RIBET C., CASTAN-LAURELL I., DAVIAUD D., GUIGNE C., LANGIN D. and VALET P.: The transcriptional co-activator PGC-1 a up regulates apelin in human and mouse adipocytes. Regulatory Peptides, 150: 33-7, 2008.

69- CATALANO P.M., NIZIELSKI S.E., SHAO J., PRESTON L., QIAO L. and FRIEDMAN J.E.: Downregulated IRS1 and PPARgamma in obese women with gestational diabetes: Relationship to FFA during pregnancy. Am. J. Physiol. Endocrinol. Metab., 282: E522-E33, 2002.

70- CHEN Y.P., LI J., WANG Z., REICHETZEDER C., XU H., GONG J., CHEN G., PFAB T., XIAO X. and HOCHER B.: Renin Angiotensin Aldosterone System and Glycemia in Pregnancy. Clin. Lab., 58: 527-33, 2012.

71- MILLER J.A., FLORAS J.S., ZINMAN B., et al.: Effect of hyperglycaemia on arterial pressure, plasma renin activity and renal function in early diabetes. Clin. Sci., 90: 189-95, 1996.

72- LIM H.S., MACFADYEN R.J. and LIP G.Y.H.: Diabetes Mellitus, the Renin-Angiotensin-Aldosterone System, and the Heart. Arch. Intern. Med., 164 (13): 1737-48, 2004.

73- TENG X., QI Y., LU Z., ZHOU Y., CAI Y. and TANG C. Contradictory role of apelin in vascular calcification. Proceedings of The Physiological Society., 37 th Congress of IUPS (Birmingham, UK), PCD374, 2013.

74- ZHOU Q.G., HOU F.F., GUO Z.J., LIANG M., WANG G.B. and ZHANG X.: 1,25-dihydroxy Vitamin D improved 
the free fatty-acid-induced insulin resistance in cultured C2C 12 cells. Diabetes/Metabolism Research and Reviews, 24 (6): 459-64, 2008.

75- MAESTRO B., CAMPION J., DAVILA N. and CALLE C.: Stimulation by 1,25-dihydroxy Vitamin D3 of insulin receptor expression and insulin responsiveness for glucose transport in U-937 human promonocytic cells. Endocrine Journal, 47 (4): 383-91, 2000.

76- BOURLON P.M., BILLAUDEL B. and FAUREDUSSERT A.: Influence of vitamin D3 deficiency and 1,25 dihydroxyvitamin D3 on de novo insulin biosynthesis in the islets of the rat endocrine pancreas," Journal of Endocrinology, 160 (1): 87-95, 1999.

77- MAESTRO B., DAVILA N., CARRANZA M.C. and CALLE C.: Identification of a Vitamin D response element in the human insulin receptor gene promoter. Journal of Steroid Biochemistry and Molecular Biology, 84 (2-3): 223-30, 2003.

78- YUE P., JIN H., XU S., AILLAUD M., DENG A.C., AZUMA J., KUNDU R.K., REAVEN G.M., QUERTERMOUS T. and TSAO P.S.: Apelin Decreases Lipolysis via $\mathrm{G}_{\mathrm{q}}, \mathrm{G}_{\mathrm{i}}$, and AMPK-Dependent Mechanisms, Endocrinology, 152 (1): 59-68, 2011.

79- TASCI I., ERDEM G., OZGUR G., TAPAN S., DOGRU
T., GENC H., ACIKEL C., OZGURTAS T. and SONMEZ A.: LDL-cholesterol lowering increases plasma apelin in isolated hypercholesterolemia. Atherosclerosis, 204 (1): 222-8, 2008.

80- KUO Y.T., KUO C.H., LAM K.P., CHU Y.T., WANG W.L., HUANG C.H. and HUNG C.H.: Effects of Vitamin D3 on Expression of Tumor Necrosis Factor- $\mathrm{a}$ and Chemokines by Monocytes. Journal of Food Science, 75 (6): H200-H204, 2010.

81- LI Y.C., KONG J., WEI M., CHEN Z.F., LIU S.Q. and CAO L.P.: 1,25-Dihydroxyvitamin D3 is a negative endocrine regulator of the renin-angiotensin system. Journal of Clinical Investigation, 110 (2): 229-38, 2002.

82- KONG J., QIAO G., ZHANG Z., LIU S.Q. and Y.C. LI: Targeted Vitamin D receptor expression in juxtaglomerular cells suppresses renin expression independent of parathyroid hormone and calcium. Kidney International, 74 (12): 1577-81, 2008.

83- DUNLOP T.W., VÄISÄNEN S., FRANK C., MOLNÁR F., SINKKONEN L., CARLBERG C. and KARN J.: The human peroxisome proliferator-activated receptor $\mathrm{S}$ gene is a primary target of $1 \mathrm{a}, 25$-dihydroxyvitamin D3 and its nuclear receptor. Journal of Molecular Biology, 349 (2): 248-60, 2005. 


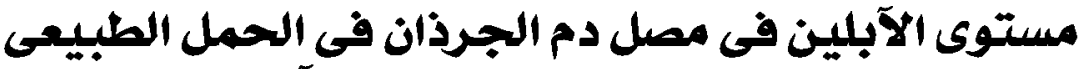

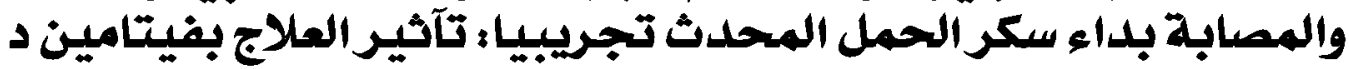

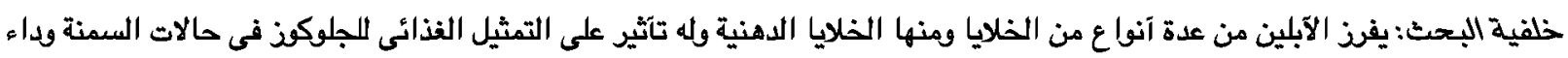

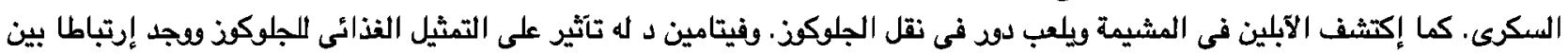

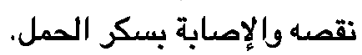

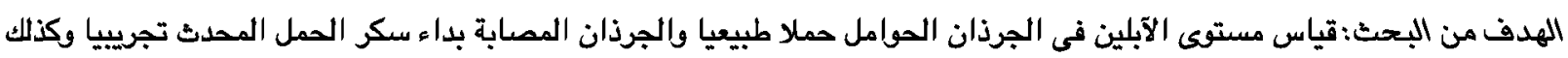

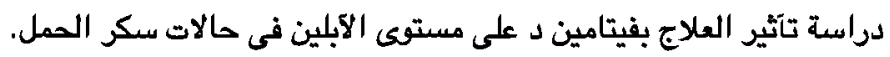

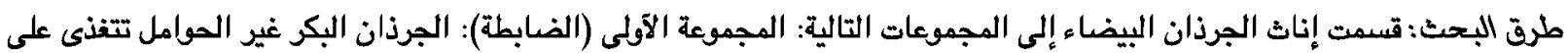

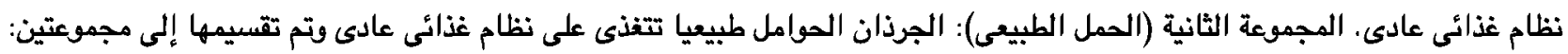

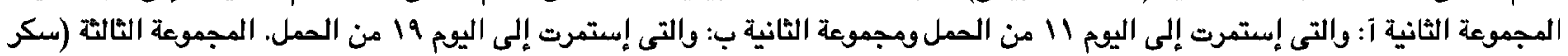

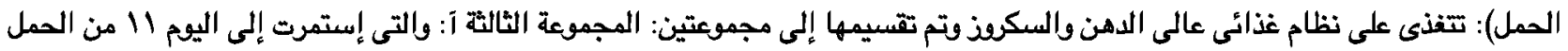

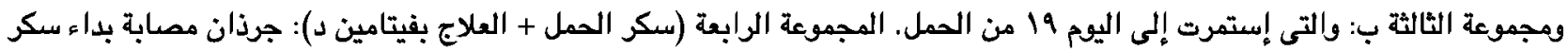
الحمل وتم إعطائها فيتامين د من الئهم اليوم .1 إلى اليوم اليوم 19 من الحمل.

وتم قياس كل من مؤشر كتلة الجسم، مستويات الآبلين، الدهون الثلاثية، الكوليسترل الكلى والكوليسترول العالى الكثافة، الكوليسترول

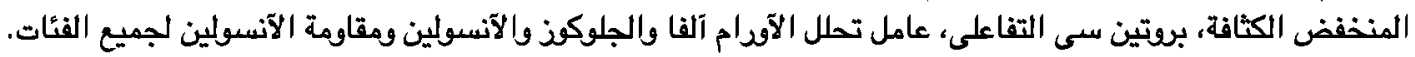

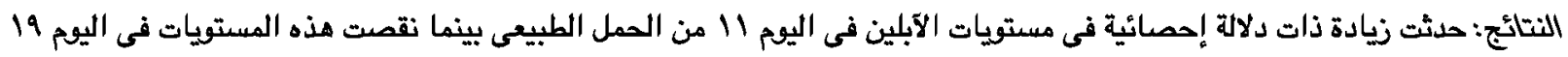

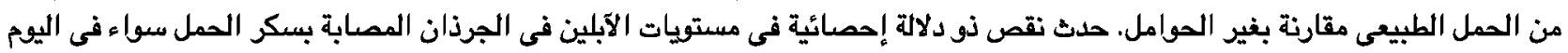

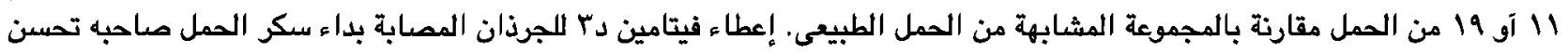
فى مستوى السكر ومقاومة السكر ومقاو مة الإنسولين مع زيادة ذات السمل دلالة إحصائية فى مستويات الآبلين.

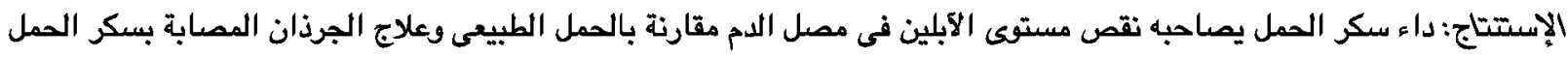

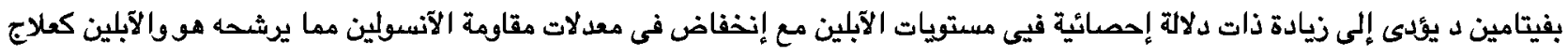
محتمل لسكر الحمل. 